DOI: $10.2478 / \mathrm{v} 10025-010-0024-7$

JOURNAL OF WATER

AND LAND DEVELOPMENT

J. Water Land Dev. No. 13a, 2009: 133-148

\title{
Forestry and water budget of the lowlands in northeast Germany - consequences for the choice of tree species and for forest management
}

\author{
Jürgen MÜLLER
}

Institute for Forest Ecology and Forest Inventory, Alfred-Möller-Str. 1, 16225 Eberswalde, Germany, fax: 0049-3334-65354; e-mail: juergen.mueller@vti.bund.de

\begin{abstract}
The lowlands in northeast Germany are among the driest and at the same time the most densely wooded regions in Germany. Low annual precipitation between 500 and $600 \mathrm{~mm}$ and the light sandy soils with their low water storage capacity and high porosity lead to limited water availability. Therefore the hydrological functions of forests play an important role in the fields of regional water budget, water supply and water distribution. To investigate the water consumption of different tree species, lysimeters were installed at Britz near Eberswalde under comparable site conditions. Nine large-scale lysimeters, each with an area of $100 \mathrm{~m}^{2}$ and $5 \mathrm{~m}$ deep, were built in the early $1970 \mathrm{~s}$. In 1974 the lysimeters were planted with Scots pine (Pinus sylvestris L.), common beech (Fagus sylvatica L.), larch (Larix decidua L.) and Douglas fir (Pseudotsuga menziesii (Mirb.) Franco) as experimental stands of 0.3 ha each according to the usual management practices. The areas surrounding the lysimeters were planted similarly. The tree species is of outstanding importance for deep seepage under forest stands. Under the given precipitation and soil conditions, the course of interception and hence, the amount of seepage water depend on the crown structure in the stand. Depending on the amount of interception of the tree canopy and the duration of the leaching phase in spring, the mixed stands range between pure pine and pure beech. Making use of silvicultural methods and adequate stand treatment, forestry is able to control the water budget of landscapes.
\end{abstract}

Key words: crown architecture, evapotranspiration, forest lysimeter, interception, seepage water, tree species, water budget

\section{INTRODUCTION}

At present about $28 \%$ - i.e. 1.9 million hectares - of the lowlands in northeast Germany are covered with forests. In natural forests, beech would be dominant, with pine being restricted to the poorer and drier sites. As a result of human trade during the past 200 years the potentially natural distribution of tree species varies greatly from the one currently found (Tab. 1). Structural changes resulted in exten- 
Table 1. Potentially natural and current distributions (in \%) of tree species in the forests of the lowlands in northeast Germany (HofMANN, 1996)

\begin{tabular}{lcc|c}
\hline \multicolumn{1}{c}{ Tree species } & Potentially natural & Current & Difference \\
\hline Beech & 42.5 & 4.3 & -38.2 \\
Oak & 28.9 & 4.9 & -24.0 \\
Hornbeam & 8.1 & 0.3 & -7.8 \\
Scots pine & 9.0 & 70.3 & +62.3 \\
\hline
\end{tabular}

sive pine monoculture stands that now cover more than $70 \%$ of the forests and are far from natural.

Therefore forestry has made great efforts to bring forest structures back to almost natural conditions and to establish stable mixed forests on suitable sites. Future forests in the lowlands in northeast Germany shall consist of a great variety of species, a target which is also pursued by forest conversion in the German Land of Brandenburg.

The present paper concentrates on changes of the water budget in pine-beech mixed stands compared with pure pine and beech stands and on the ensuing consequences, with special consideration of the following scientific problems:

- Impact of tree species, stand age and stand structure on the rates of interception by canopy, tree transpiration and evapotranspiration of ground vegetation.

- Effect of mixed stands and pure pine and beech stands on seepage water and on the water budget of landscapes.

The redistribution of precipitation by main canopy and understorey, the physiology of water absorption by pine and beech, and the seepage under pine-beech mixed stands are largely unknown scientific territory and therefore a point of great interest against the background of potential climate warming.

\section{SITE CONDITIONS}

As vast stretches of the lowlands in northeast Germany fall under the influence of continental climate, precipitation is far below the national average and the available water resources are inadequate. Annual precipitations range between 450 $\mathrm{mm}$ in the valley of River Oder and $750 \mathrm{~mm}$ in the mountain range of "Hoher Fläming" in the southwest of Brandenburg.

The climatic water balance (CWB), i.e. the difference between total precipitation and potential evaporation, is one of the most common quantities for describing regional moisture conditions. Annual records reveal distinct differences between northeast Germany with its negative CWB and the other regions of Germany with their mostly positive CWB. More important for forest growth is the water supply during the vegetation period. Low- or no-rainfall periods and negative climatic wa- 
ter balances during the vegetation period are typical of the lowlands in northeast Germany. The course of the CWB during the vegetation periods 1999-2005 shows the distinct negative record in 1999 and 2003 with their very dry summers and extreme drought stress on plant growth (Fig. 1). Dry phases during the vegetation period with a distinct negative CWB are typical of that region even in "normal" years.

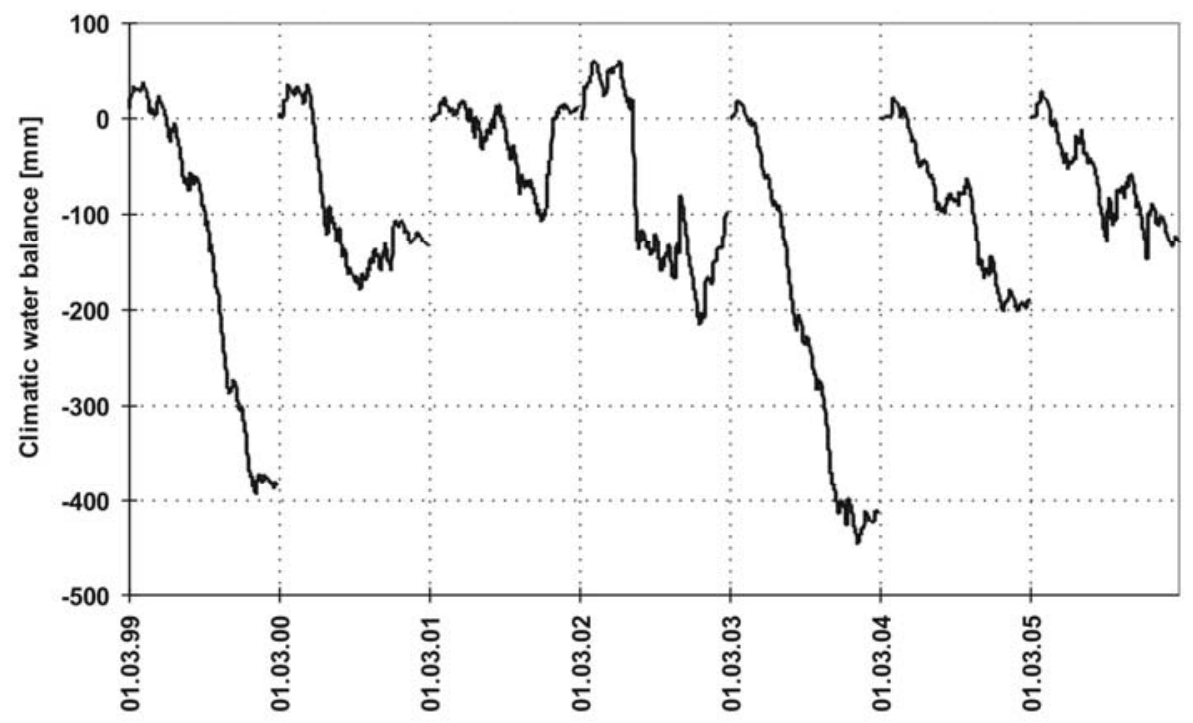

Fig. 1. Cumulative climatic water balance of the Forest Research Station Britz 1999-2005

The soils are mostly sandy with low water storage capacity and high porosity. The usable field capacity $1 \mathrm{~m}$ below surface is only $100 \mathrm{~mm}$. Since 1960 downward trends of the upper aquifer have prevailed in Brandenburg. Between 1980 and 1999 these deficiencies were most pronounced ( $76 \mathrm{~cm}$ on an average) in the higher elevations. This seems to have been due to intensive farmland drainage by human interference, to the established rise in temperatures over the past decades and increased evaporation.

In this context the hydrological functions of forests play an important role when conducting investigation on regional water budget, water supply and water distribution. This, in turn, requires detailed and precise records and parameters above all for determining natural groundwater recharge on the various sites and catchment areas by means of sound water budget models. Larger gaps in such knowledge exist for the wooded sites which, however, have become more and more important for water supply as here the groundwater is still very clean over large areas. 


\section{MATERIALS AND METHODS}

Precipitation gets redistributed in different ways and in part consumed by the tree and shrub layers and ground vegetation. It is reaching the forest soil as stem flow and throughfall, replenishes the soil water reservoir and seeps down below the main root zone into the groundwater. Interception and evapotranspiration of trees, shrubs and ground vegetation as well as evaporation from the forest soil are the components of consumption. Close correlations exist between the vegetation structures and the water flux processes (Fig. 2).

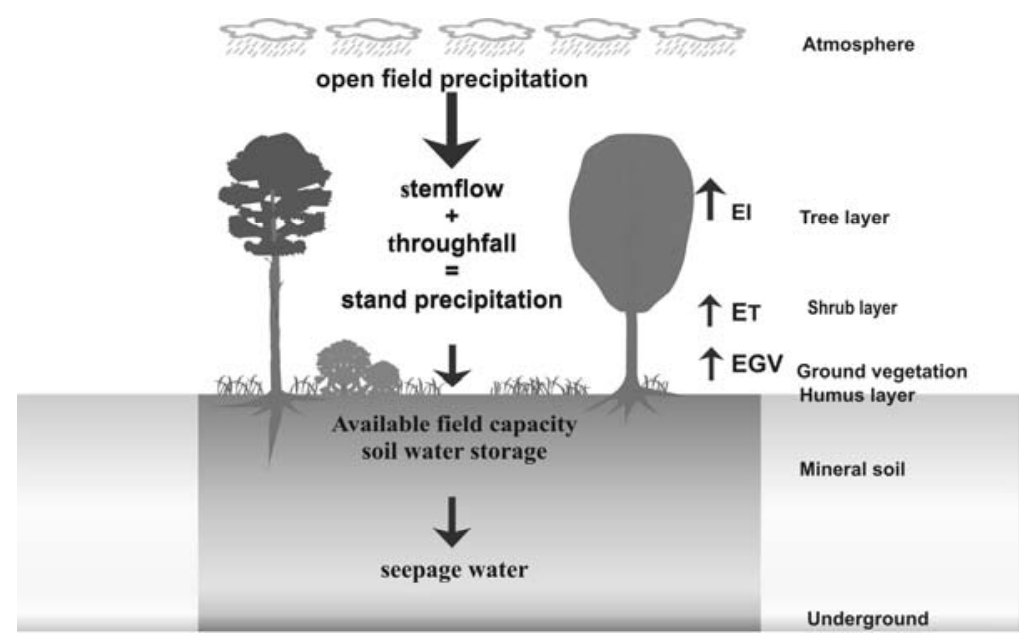

Fig. 2. Water fluxes in forest ecosystem

Quantification of water flux in the stands has been an essential element of the investigations.

Water budget investigations in different ecosystems often suffer from different or insufficiently controlled boundary conditions of the test plots. This may obliterate and distort the effect of the very factor of interest. When investigating the impact of vegetation on the total water budget for loose rock soils in particular, interfering boundary conditions are most reliably eliminated by measuring in lysimeters. Provided that the lysimeters are properly designed and dimensioned, this applies to forest ecosystems as well.

Beginning in 1972, therefore nine large-scale lysimeters were built at Britz (close to Eberswalde). Making use of other lysimeter experience, they were set up to the depth of $5 \mathrm{~m}$ each - as required for forest lysimeters - and $100 \mathrm{~m}^{2}(10 \mathrm{~m} \mathrm{x}$ $10 \mathrm{~m}$ ) surface area (MÜLLER, 1993). Therefore the "large-scale lysimeters of Britz" are unparalleled in Europe as other lysimeters grown with trees have the required surface area, but with $2.5 \mathrm{~m}, 3 \mathrm{~m}$ or $3.5 \mathrm{~m}$ they are not deep enough in Castricum in 
the Netherlands (Hoeven, 2005), in St. Arnold in Land Niedersachsen (SCHROEDER, 1990) and in the Letzlinger Heide in Land Sachsen-Anhalt (HELBIG, 1988).

The lysimeters were turned into an ecological experiment station for keeping track of the growth of major tree species of the region right from planting and investigating their matter circulation and water budget parameters.

The experiment station is located $5.5 \mathrm{~km}$ north-east of Eberswalde on the large plane main terrace of the Eberswalde glacial valley (Tab. 2). The soil consists of medium-grained sand throughout the lysimeter profile down to $5 \mathrm{~m}$ deep. The site is representative of large parts of the lowlands in the lowlands of northeast Germany.

Table 2. Site conditions of the lysimeter station

\begin{tabular}{llc}
\multicolumn{1}{c|}{ Characteristic parameter } & Value \\
\hline Height above sea level, $\mathrm{m}$ & & 40 \\
Soil type & & Haplic Podzol \\
Soil granulation to 5 m depth, \% $\quad$ rough sand & middle sand & 2 \\
& fine sand & 75 \\
& clay and silt & 19 \\
& 4 \\
Long-term annual average of precipitation, mm & 570 \\
Long-term annual average of air temperature, ${ }^{\circ} \mathrm{C}$ & 8.2 \\
\hline
\end{tabular}

In 1974 the lysimeters were planted, together with their neighbouring area with Scots pine (Pinus sylvestris L), common beech (Fagus sylvatica L.), larch (Larix decidua L.) and Douglas fir (Pseudotsuga menziesii (Mirb.) Franco) as experimental stands of 0.3 ha each according to the usual management practices (Fig. 3 ). The seepage water accumulating above the lysimeter bottom flows to a measuring shaft on the side of the lysimeter and gets mechanically metered and recorded with an electric facility (Fig. 4). Total evaporation $E$ is calculated with the water budget equation:

$$
E=P-S-\Delta W
$$

where: $P$ - precipitation; $S$ - seepage; $\Delta W$ - change of soil water content

Table 3 shows the structure-relevant parameters of the lysimeter stands before the beginning of forest conversion in 1999.

It was the initial aim of the experiment to find out the influence of the species and age of the growing trees (pine, larch, beech, Douglas fir) on identical sandy soil under comparable weather conditions on both natural groundwater recharge and evaporation. 


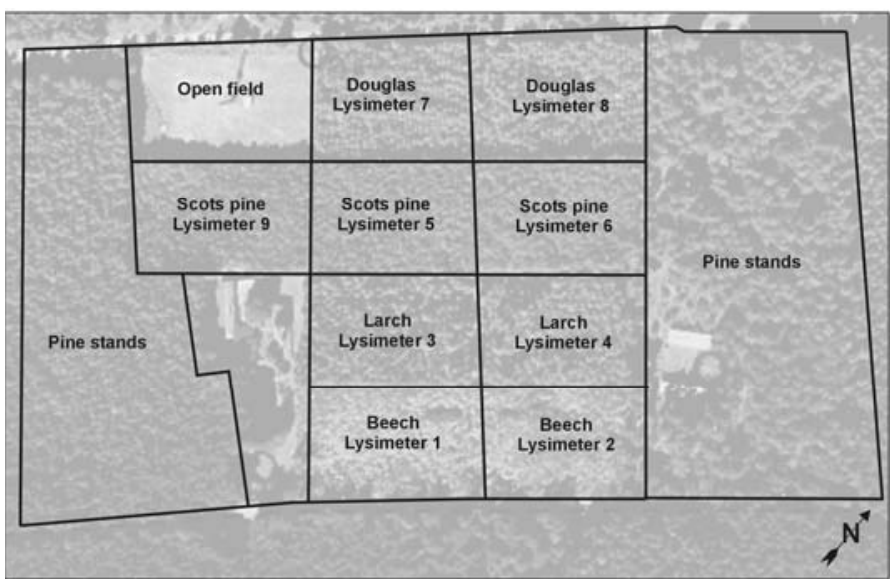

Fig. 3. Aerial view of the ecological experiment station Britz with location of the large-scale lysimeters (1998)

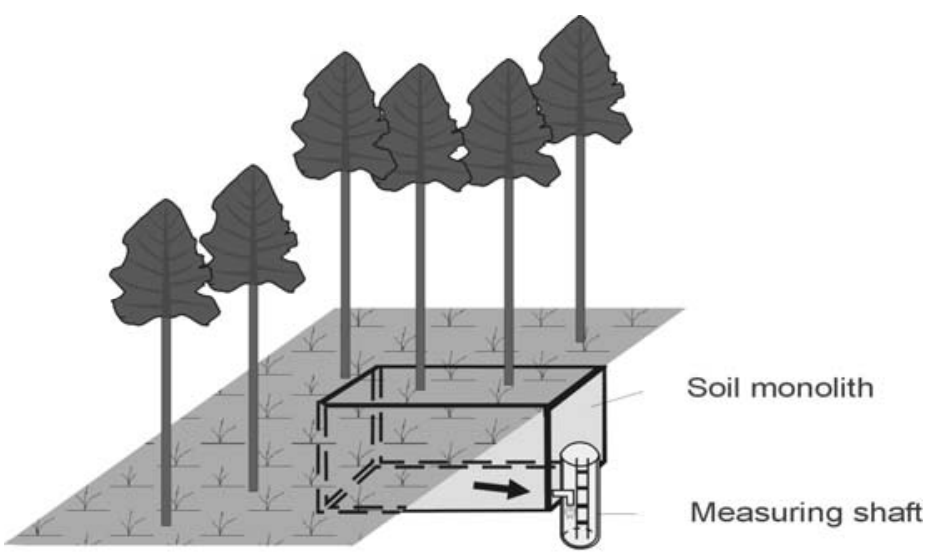

Fig. 4. Principle of a large-scale lysimeter planted with trees

Table 3. Structure-relevant parameters of the lysimeter stands in 1999 before forest conversion (age of trees: 27 years)

\begin{tabular}{l|c|c|c|c}
\hline \multicolumn{1}{c|}{ Parameter } & Scots pine & Beech & Larch & Douglas fir \\
\hline Height of mean basal area stem, m & 12.8 & 8.6 & 13.2 & 11.0 \\
Diameter of mean basal area stem, cm & 10.9 & 5.5 & 13.9 & 12.2 \\
Stem number, piece $\cdot \mathrm{ha}^{-1}$ & 2400 & 9000 & 1700 & 2800 \\
Basal area, $\mathrm{m}^{2} \cdot \mathrm{ha}^{-1}$ & 28.0 & 21.1 & 29.5 & 32.3 \\
Degree of stocking density, - & 1.21 & 1.40 & 1.20 & 1.05 \\
\hline
\end{tabular}

Future forests in the lowlands of northeast Germany shall be mixed stands with as large a number of different species as possible. And this is also the aim of forest conversion in Land Brandenburg. The programme requires scientific atten- 
dance and foundation. In particular it shall be examined how the hydro-ecological conditions - which often are the limiting factor for forest growth in this area would change with underplanted pine and larch and how these conditions may benefit from stand-structural and forest management. Moreover, for site-climatic reasons oak is becoming more important in the lowlands of northeast Germany, but the hydrological conditions of developing oak ecosystems are still relativly unknown. This is why several lysimeter stands were changed as follows in 2000:

- Larch underplanted with beech,

- Scots pine underplanted with beech,

- Scots pine underplanted with oak,

- Newly planted oak.

Along with these structural changes of the stands, more extensive measuring systems were installed in the test plots.

The water balance results of pure pine and beech stands are derived not only from lysimeter research but also from investigations in mature stands outside the lysimeters.

The results of deep seepage and evaporation were obtained by measuring the water fluxes in the stands and soil and by recording the transpiration rates (Granier sensors) of trees.

In Scots pine forest ecosystems of the lowlands in northeast Germany the evapotranspiration of four ground vegetation types (Calamagrostis epigeios, Deschampsia flexuosa, Deschampsia flexuosa with Rubus idaeus, and Vaccinium myrtillus) was investigated by means of innovative measuring methods, using newly developed weighable lysimeters (surface $1 \mathrm{~m}^{2}$, depth $1.8 \mathrm{~m}$ ) for separate determination of tree transpiration and evapotranspiration from the forest soil (Fig. 5). The ground vegetation species in each lysimeter were grown in undisturbed soil monoliths, and evapotranspiration was determined indirectly as loss with $0.1 \mathrm{~mm}$ accuracy by means of an integrated scale system.

These investigations have shown that the evapotranspiration of the ground vegetation increases along with the grass cover and is lower under dwarf shrubs. During periods of water shortage, higher water consumption by the grasses may reduce the amount of water that is available to the trees (MÜLLER et al., 1998).

Figure 6 shows the experimental plot design as a chrono-sequence of the developing pine-beech mixed stands and of pure stands of pine and beech of similar age. Hydrologically relevant parameters of stand structure have been compiled from the intensively examined sites with largely similar soil conditions outside the lysimeters.

The precipitation falling on the main canopy gets redistributed and consumed by the different vegetation layer. Redistribution and consumption are measured at the bounds of the compartments. Unlike in pure stands, the throughfall that reaches the zone below the main pine canopy or above the beech crowns is measured in 


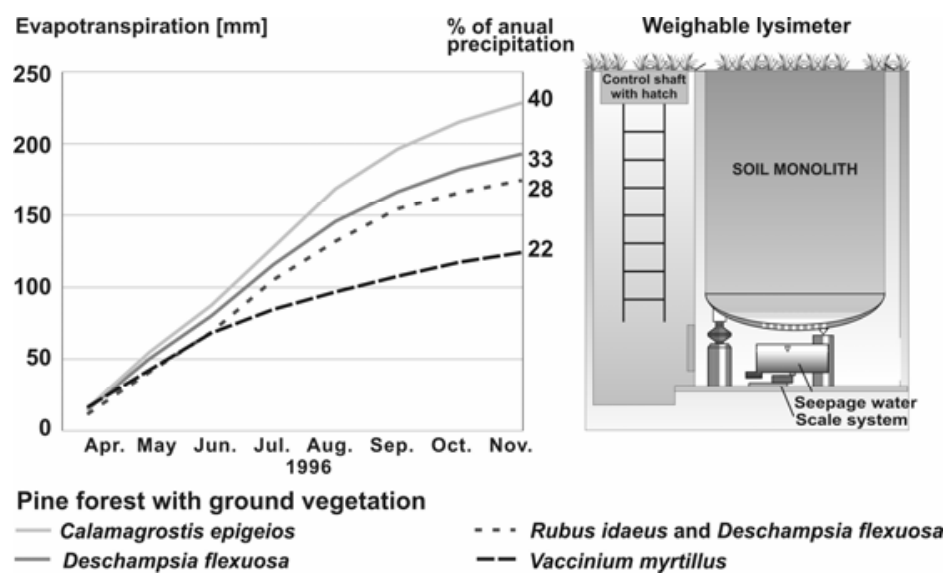

Fig. 5. Evapotranspiration of ground vegetation species in Scots pine forest ecosystems

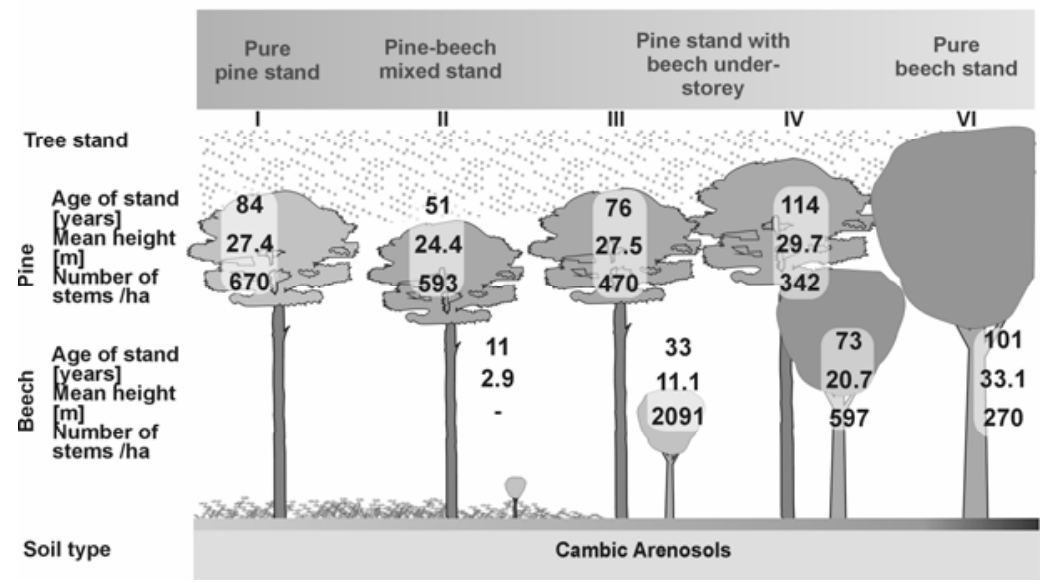

Fig. 6. Hydro-ecologically relevant parameters of a chrono-sequence for forest conversion

addition. The structural characteristics of forest ecosystems - such as space-filling, tree height and roughness of the evaporating surfaces, pronounced vertical stand structure and spread in the landscape - have an essential influence on the total amount of evaporation and therefore on all the other parameters of the water budget (MÜLLER, 2002). Stand structures show great variability in terms of time and space above all in the conversion stages above the understorey. This results come from the different dimensions of the trees of the main canopy and of the (intermediate and) understorey(s) and from the distribution of the tree species in the stand (MÜLLER et al., 2002).

With the investigations it has become possible to assess the long-term consequences of forest conversion for the regional water budget. 


\section{RESULTS AND DISCUSSION}

The tree species is of outstanding importance for deep seepage under forest stands. Fig. 7 shows the development of deep seepage under the different species from 1978 to 1998 .

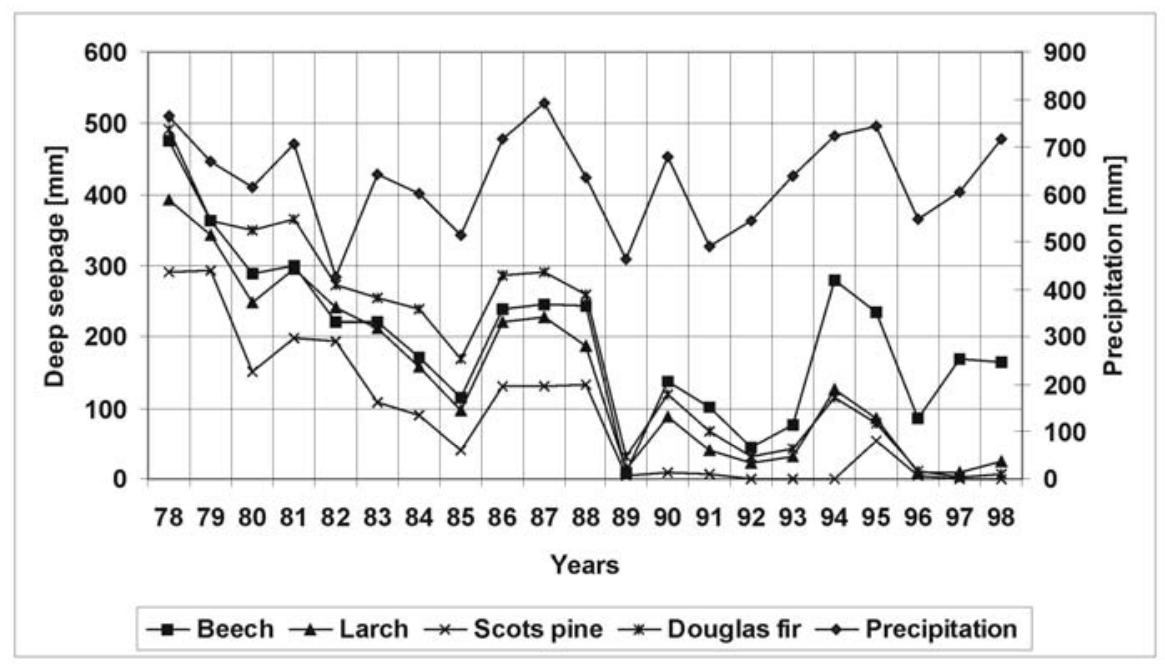

Fig. 7. Annual precipitation and annual deep seepage 1978-1998 of forest stands at the lysimeter station Britz

Different phases of annual seepage rates were recorded for the tree species during the test periods 1978-1984, 1985-1989 and 1990-1998 (calendar years) (Tab. 4).

Table 4. Means of annual precipitation and seepage for the tree species under review

\begin{tabular}{lcc|c}
\hline \multicolumn{1}{c}{ Parameter } & $1978-1984$ & $1985-1989$ & $1990-1998$ \\
\hline Precipitation, mm & 633 & 625 & 633 \\
Deep seepage, mm & & & \\
- douglas fir & 334 & 208 & 53 \\
- beech & 292 & 170 & 144 \\
- larch & 270 & 149 & 49 \\
- scots pine & 190 & 88 & 8 \\
\hline
\end{tabular}

Seepage declined significantly until 1984 with all tree species under review (Fig. 7). This strong decline under young growing trees was due to increasing total evaporation $E$. During that period the seepage of the growing stock increased quickly from initially minimal amounts to really high values, a fact that influenced 
each of the three elements of total evaporation $E=E_{G V}+E_{T}+E_{I}$. Transpiration $E_{T}$ and interception $E_{I}$ increased continuously, but $E_{G V}$, the evapotranspiration of soil and ground vegetation, decreased.

At first the trend of decreasing seepage came to an end in 1985. Then seepage increased by between 90 and $120 \mathrm{~mm}$, depending on the tree species, and remained almost constant in 1987 and 1988. The wet years of $1986(718 \mathrm{~mm}), 1987$ (793 $\mathrm{mm})$ and in part also $1988(635 \mathrm{~mm})$ with monthly precipitation of more than 100 $\mathrm{mm}$ then resulted in high seepage rates in each species (Fig. 7). The strong decline of natural groundwater recharge in 1989 was due to the lack of rain in that year (462 mm).

Due to the extreme alternation of wet years (1986, 1987 and to some extent also 1988$)$ and dry ones $(1985,1989)$ the influence of dendromass was masked by the impact of precipitation between 1985 and 1989.

Between 1990 and 1998 seepage differed by tree species. The trend of decreasing seepage continued with Scots pine, Douglas fir and larch. Average annual seepage under pine was $8 \mathrm{~mm}$ during that period. No seepage was found in five of these nine years. Seepage under Douglas fir and larch declined strongly from 1996 on, with $6 \mathrm{~mm}$ under Douglas fir and $14 \mathrm{~mm}$ under larch on an annual average from 1996 to 1998. Only in the wet years of 1994 and 1995 (725 mm and $744 \mathrm{~mm}$, respectively) seepage under these species increased significantly again (Fig. 8).

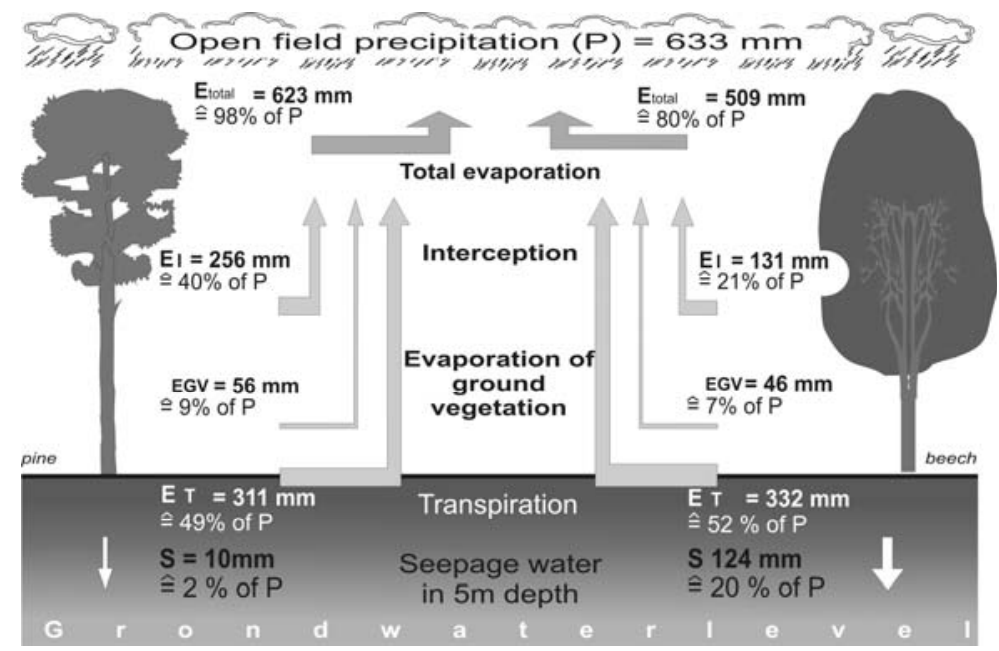

Fig. 8. Water budget balance of young pine and beech stands on the large-scale lysimeters of the ecological experiment station Britz 1992-1999

The various evaporation components (interception, transpiration and evaporation) of the forest ground vegetation need to be analysed in order to find out why seepage rates were so different between the tree species. Figure 8 illustrates the wa- 
ter budget balance for the lysimeter species beech and Scots pine between 1992 and 1999.

The differences in seepage were mainly due to interception, (accounting for $21 \%$ and $40 \%$ of the mean annual precipitation in the beech and pine stands of the same age, respectively. In beech, foliation differs from season to season (green in summer, bare in winter), branches and twigs feed water to the stem like a funnel, the stem is smooth with but few stem interceptions, and the number of stems per unit area is high (ca. 9000 stems per ha). All this resulted in stem flow of up to 6$-8 \%$ of the open field precipitation already in the young stands and, hence, interception was altogether low. The higher interception in pine stands compared with beech was due to the fact that pine is evergreen and therefore highly interceptive throughout the year, that it has an open, awkward shaped crown (intercepting funnel) and - due to its rough bark - low to even negligible stem flow. The latter applies above all to timber wood of higher age.

Regarding their interception, larch and Douglas fir range between Scots pine and beech. Seepage quantities under the four tree species (beech $124 \mathrm{~mm}$, larch 45 $\mathrm{mm}$, Douglas fir $41 \mathrm{~mm}$, Scots pine $10 \mathrm{~mm}$ on an average) followed the average rate of interception 1992-1999.

The pure pine stand (28 years old) on the large-scale lysimeter station of Britz that was underplanted with beech and oak, respectively, in 1999 revealed already an effect of pine thinning on the seepage quantities recorded $5 \mathrm{~m}$ below surface. In the course of thinning the basal area decreased from $34.5 \mathrm{~m}^{2} \cdot \mathrm{ha}^{-1}$ to $23 \mathrm{~m}^{2} \cdot \mathrm{ha}^{-1}$ in beech and from $34.5 \mathrm{~m}^{2} \cdot \mathrm{ha}^{-1}$ to $24.3 \mathrm{~m}^{2} \cdot \mathrm{ha}^{-1}$ in oak. While seepage continued to be low in the pure pine stand, seepage in the underplanted lysimeters accounted already for $5 \%$ of the mean precipitation of $637 \mathrm{~mm}$. This was due to the lower interception of the pine canopy and to the lower evapotranspiration of the stands because of the smaller number of trees per unit area.

On an average of the years 1999-2003, 52\% of the $637 \mathrm{~mm}$ mean precipitation reached the bottom of the lysimeter planted with oak in 1999. Interception and evapotranspiration of the small oak trees were still low and seepage was high accordingly. The share of seepage of the small oak trees 7 years old was about similar to that of young beech trees of the same age (MÜLLER, 2001; 2002).

Figure 9 shows the trends of evaporation and seepage water in pure pine and beech stands and in a pine-beech mixed stand at different ages. Total evaporation rises fast in the growing pine stand, and seepage water goes down. In 30 years old pine stands total evaporation comes up to $100 \%$ due to high interception and transpiration rates as pine stands of that age stand out for their large stem numbers per unit area, close canopies and culminating increment. Seepage water in those stands comes close to zero. Due to naturally declining tree numbers and selective thinning according to schedule, transpiration and interception decrease steadily and the amount of seepage water increases. In the mature pine stand with its thinner can- 


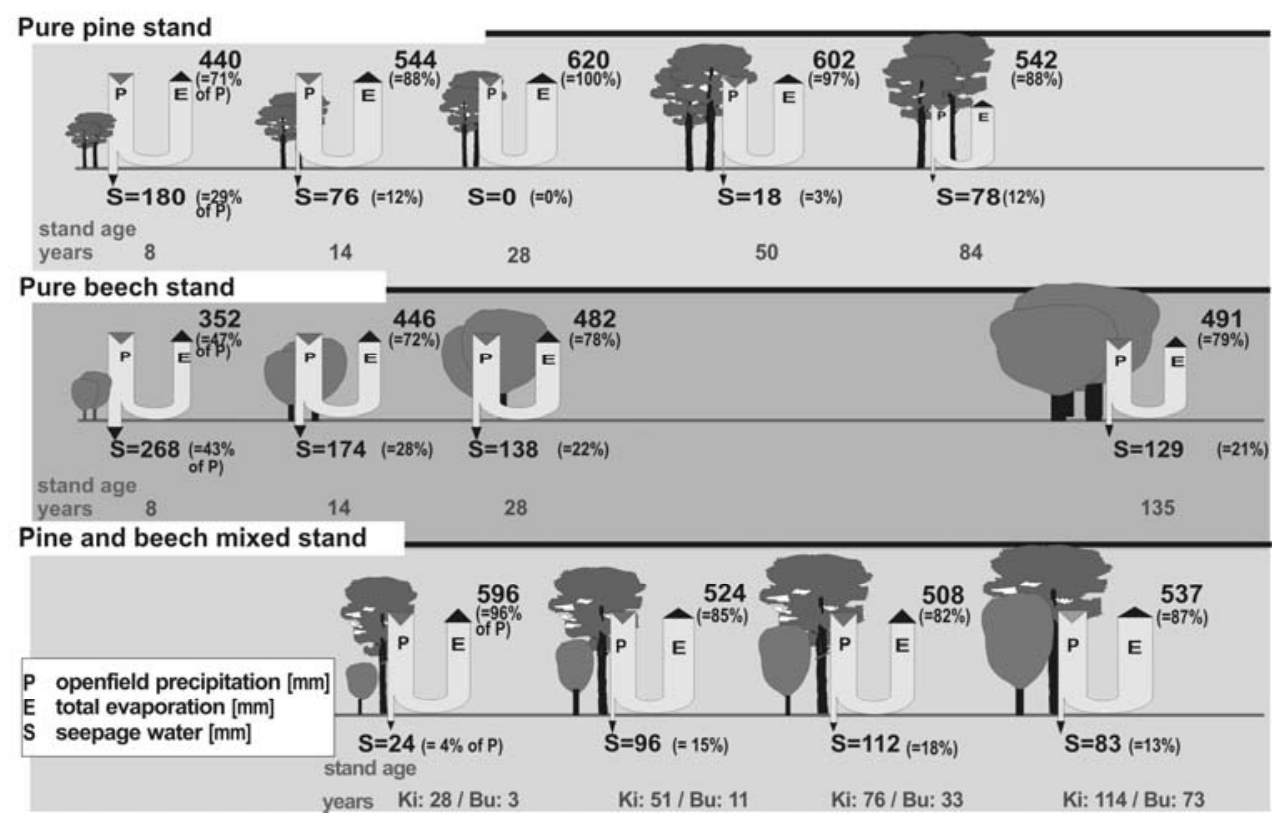

Fig. 9. Water balance of pure pine and beech stands and of pine-beech mixed stands at different stand ages (620 $\mathrm{mm}$ open field precipitation, sandy soil)

opy the share of ground vegetation evapotranspiration increases significantly and seepage water comes up to almost $12 \%$ of the annual precipitation.

Evaporation in the growing beech stand rises also fast. In a 30 years old stand total evaporation comes up to almost $80 \%$ of the annual precipitation and it remains constant until the trees have reached full maturity. Seepage water is quite constant with more than $20 \%$ of the annual precipitation. As the trees grow up, transpiration increases slightly and interception decreases due to increasing stem flow (reaching about $20 \%$ of the annual open field precipitation). Evaporation from the forest soil is of minor importance because it is quite dark under beech trees. At all ages of the trees the amount of seepage water is higher under beech than under pine. Under comparable soil and weather conditions, for example, each year about $50 \mathrm{~mm}$ more precipitation get into the soil under mature beech than under mature pine (MÜLLER, 2003; 2005).

Investigations in pine-beech mixed stands of different age on sandy soil have shown that the amount of seepage water is between that of pure pine and pure beech stands, a fact that depends on silvicultural measures leading to decreasing stand density and also on the development of the beech tree dimensions (MÜLLER et al., 2002).

Total evaporation gives only a rough survey of the water budget of the forest stand. The clarification of interactions between compartments benefits more when 
breaking the total evaporation up into its various components (crown interception, evapotranspiration of soil and ground vegetation, transpiration of trees). Figure 10 shows the order of dimensions of the evaporation components during the vegetation period in a pure pine stand, in a pure beech stand and in the pine-beech mixed stands under review. In pure pine-grass forests the transpiration of trees and the evapotranspiration of ground vegetation can be approximately the same. In beech forests on sandy soil with little ground vegetation due to the lack of light most of the water gets evaporated by the trees. As beech is growing more and more into the pine crowns along with reduced evaporation from the forest ground, the evaporation relations of the pine-beech mixed stand reach those of the pure beech stand.

The amount and temporal course of evaporation by the ground vegetation will influence the quantity of the water, and its availability in the soil is decisive for the water consumption of the tree layer.

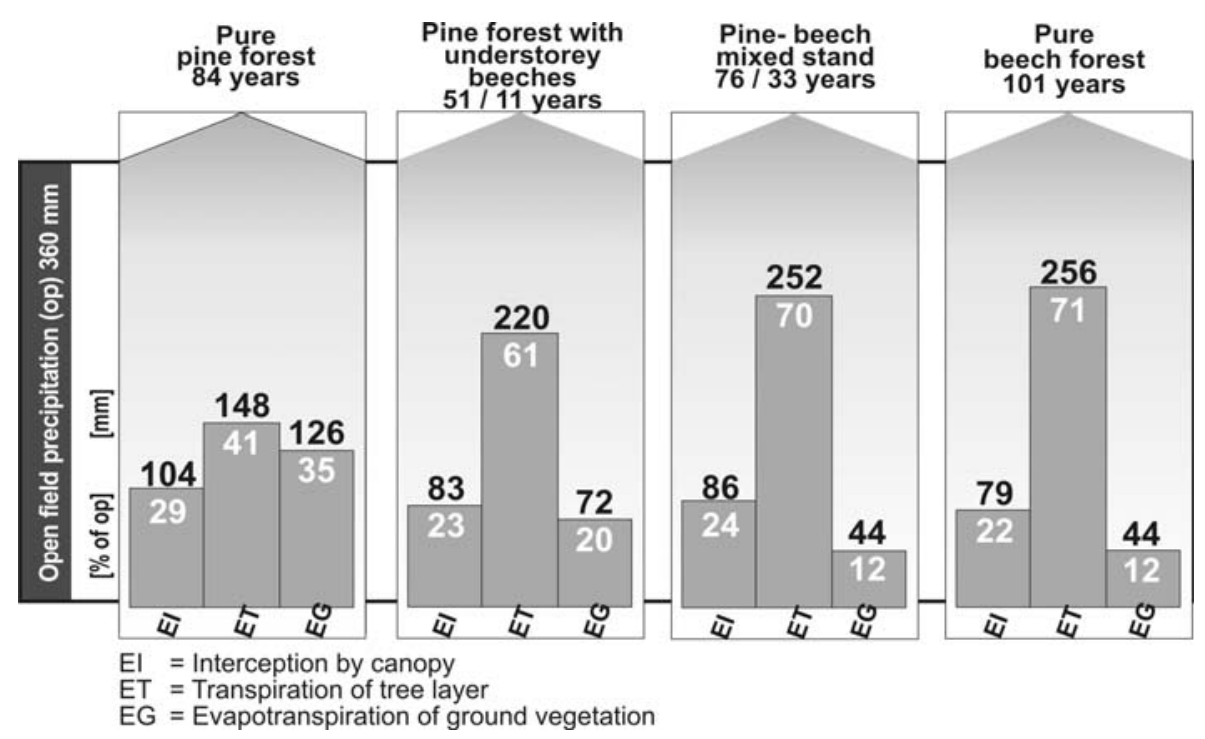

Fig. 10. Evaporation components during summer in pure pine and beech stands and in pine-beech mixed stands (sandy soil)

\section{CONCLUSIONS}

Forests with their special hydrological properties have a substantial influence on the water budget, water supply and water distribution of entire landscapes. The regional water balance can be influenced above all by choosing tree species that are suitable for a given site. Taking specific characteristics of the forest composition into account, it will be possible to determine hydro-ecological effects. The crown architecture has a decisive influence on the amount of seepage water and on the 
distribution of precipitation in forest stands and is essential to the availability of soil water.

Precise assessment of the ecological effects of the understorey becomes possible only when considering the specific features of the structural composition of the pine-beech mixed stands. High-resolution biostructural analysis of the stages of tree growth under review revealed first of all precipitation gets redistributed in dependence on the structure of the stand (main canopy, understorey and/or intermediate storey) with certain impacts on the shares of the various evaporation components in total evaporation. In the end this contributes also to a changing water consumption of the stand. Depth-specific determination of soil water consumption and availability allows the causal interpretation of the growth of trees. This is particularly important in dry summer periods and allows to derive silvicultural recommendations for adequate stand density regimes.

Crown structures have a decisive bearing on the amount of seepage, the throughfall in the stand and finally on the availability of soil moisture. Appropriate strategies of forest conversion from pine forests that are far from natural to more natural stands with deciduous trees or mixed stands will contribute to higher stand stability and to a significant improvement of the hydrological efficiency of forests in the water budget of landscapes. Forest management with the regulation of stand density will help to systematically influence and to a certain extent control the water factor with regard to forest growth and the water budget of landscapes. Considering the specific site conditions and choosing suitable tree species will help to increase the available and usable water resources.

These results are important, among other things, for the afforestation of former farmland as they allow to predict the emerging hydrological situation for forest management in drinking water catchment areas and in the surrounding of urban areas where high rates of natural groundwater recharge with good water quality are a major objective of management.

\section{REFERENCES}

1. Helbig A., 1988. Vergleich der Wasserhaushaltskomponenten eines Kiefernbestandes und einer Waldgrasfläche nach Lysimetermessungen. Abhandlungen Meteorol. Dienstes DDR, 140: 123-128.

2. HOEVEN, VAN DER P.C.T., 2005. Lysimeters Castricum. Rep. 1: 61 [in Dutch].

3. HofmanN G., 1996. Vegetationswandel in den Wäldern des nordostdeutschen Tieflandes. In: Wald im Wandel. 9. Hamburger Forst- und Holztagung, 06.-09. Mai 1996. Hamburg: Max Wiedebusch Kommiss. Verl., Mitt. der Bundesforschungsanstalt für Forst- und Holzwirtschaft, 185: 45-72.

4. MÜLLER J., 1993. Die Großlysimeteranlage Britz (bei Eberswalde). Mitt. Dtsch. Bodenkundl. Ges. 71: 18-19.

5. MÜlleR J., 2001. Ermittlung von Kennwerten des Wasserhaushaltes in Kiefern- und Buchenbeständen des nordostdeutschen Tieflands. Beitr. Forstwirtsch. u. Landschaftsökologie, Berlin 35, 1: $14-18$. 
6. MÜLLER J., 2002. Wirkungszusammenhänge zwischen Vegetationsstrukturen und hydrologischen Prozessen in Wäldern und Forsten. In: Ökologie und Vegetation der Wälder Nordostdeutschlands. Ed. S. Anders. Oberwinter Verlag Dr. Kessel, 93 und 99-122.

7. MÜLLER J., 2003. Wasserhaushalt von Kiefern- und Buchen - Reinbeständen und von Kiefern- und Buchen - Mischbeständen im nordostdeutschen Tiefland. In: Bericht der 10. Lysimetertagung der Bundesanstalt für Alpenländische Landwirtschaft Gumpenstein, Irdning, 29. und 30.04.2003: 105$-109$.

8. MÜLLER J., 2005. 30 Jahre forsthydrologische Forschung auf der Großlysimeteranlage in Britz Zielstellung und Ergebnisse. In: Bericht der 11. Gumpensteiner Lysimetertagung der Bundesanstalt für Alpenländische Landwirtschaft Gumpenstein, „Lysimetrie im Netzwerk der Dynamik von Ökosystemen“, Irdning, 05. und 06.04.2005: 29-32.

9. MÜller J., BeCK W., Hornschuch F., Steiner A., 2002. Quantifizierung der ökologischen Wirkungen aufwachsender Kiefern-Buchen-Mischbestände im nordostdeutschen Tiefland. Beitr. Forstwirtsch. Landschaftsökol., 36: 125-131.

10. Müller J., Bolte A., BeCK W., Anders S., 1998. Bodenvegetation und Wasserhaushalt von Kiefernforstökosystemen (Pinus sylvestris L.). Verhandlungen der Gesellschaft für Ökologie, 28, 407-414.

11. Schroeder M., 1990. Verdunstung von Land- und Wasseroberflächen in St. Arnold bei Rheine in den Jahren 1980 bis 1987. Deutsche Gewässerkundliche Mitteilungen, 34, 4.

\section{STRESZCZENIE}

\section{Leśnictwo i bilans wodny na nizinach północno-wschodnich Niemiec - konsekwencje doboru gatunków drzew i gospodarki leśnej}

Słowa kluczowe: architektura koron drzew, bilans wodny, ewapotranspiracja, gatunki drzew, infiltracja wody, intercepcja, lizymetry leśne

Niziny północno-wschodnich Niemiec należą do najbardziej suchych i jednocześnie najbardziej zalesionych regionów Niemiec. Niski roczny opad (500-600 $\mathrm{mm}$ ) i lekkie, piaszczyste gleby o małej pojemności retencyjnej i dużej porowatości są powodem ograniczonej dostępności wody. Dlatego hydrologiczne funkcje lasu mają duże znaczenie dla regionalnych bilansów wodnych, zaopatrzenia $\mathrm{w}$ wodę i jej dystrybucji. Aby zbadać zużycie wody przez różne gatunki drzew, w Britz koło Eberswaldu zainstalowano lizymetry w porównywalnych warunkach siedliskowych. Dziewięć dużych lizymetrów o powierzchni $100 \mathrm{~m}^{2}$ i głębokości $5 \mathrm{~m}$ każdy zbudowano we wczesnych latach siedemdziesiatych XX w.. W 1974 r. lizymetry obsadzono sosną zwyczajną (Pinus sylvestris L), bukiem zwyczajnym (Fagus sylvatica L.), modrzewiem europejskim (Larix decidua L.) i daglezją zieloną (Pseudotsuga menziesii (Mirb.) Franco), tworząc eksperymentalne stanowiska zgodnie ze zwykłą praktyką leśna. Powierzchnie otaczające lizymetry obsadzono podobnie. Gatunek drzewa wpływa znacząco na głębokie przesiąkanie wody w stanowisku leśnym. W danych warunkach opadowych i glebowych przebieg intercepcji, a stąd i ilość infiltrującej wody, zależy od struktur koron drzew w stanowisku. Ze wzglę- 
du na rozmiary intercepcję przez korony drzew i długość wiosennej fazy wypłukiwania mieszane stanowiska mieszczą się między monokulturą sosnową i bukową. Dzięki stosowaniu metod upraw leśnych i odpowiednich zabiegów w stanowisku leśnictwo zdolne jest kontrolować bilans wodny w krajobrazie.

Reviewers:

Dr. Andrzej Boczoń

Prof. Waldemar Mioduszewski 